\title{
Microcosm on a bottle: experimental tests on the colonization of plastic and glass substrates in a retention reservoir
}

\author{
Tomasz Mieczan \\ Department of Hydrobiology and Protection of Ecosystems, University of Life Sciences, Dobrzańskiego 37, 20-262 Lublin, Poland
}

\begin{abstract}
The last few decades have seen a dramatic increase in water pollution due to various types of waste generated by human activity. These include plastic and glass accumulating in the shore area of lakes and oceans. These substrates may be colonized by various groups of aquatic organisms. Little is known of the trophic interrelationships between micro- and macroorganisms colonizing Plastic (PB) and Glass Bottles (GB). Therefore, the main objective of the present study was to determine the taxonomic composition and abundance of micro- and macroorganisms colonizing artificial, anthropogenic substrates, the trophic relationships between the organisms colonizing these substrates, and the influence of the physicochemical properties of the water on the formation of such assemblages. Studies of micro- and macroorganisms were carried out on the surface of PB and GB in a eutrophic retention basin. Both the species richness and abundance of microorganisms and metazoa were found to be determined by the type of substrate colonized as well as by the physicochemical properties of the water (primarily the content of total organic carbon and biogenic compounds). Furthermore, the trophic structure of microbial assemblages demonstrated seasonal variability. In spring, the substrates were colonized by typical bacterivorous ciliates, whereas in the following seasons there was a larger share of omnivorous species (ciliates and rotifers). This may indicate that the accumulation of various types of anthropogenic waste, in the present case GB and PB, may contribute to changes in the matter and energy cycle, including the carbon cycle, in various microhabitats of aquatic ecosystems.
\end{abstract}

\section{INTRODUCTION}

Pollution of water with waste generated by human activity is increasingly observed in various parts of the world. Plastic pollution in particular is observed on a vast, global scale. In addition to plastic pollution of standing waters, glass waste is becoming increasingly common, such as used bottles accumulating in the shallows of water bodies (Córaz et al., 2014; Wang et al., 2016). The total plastic load in the oceans is estimated at 5 trillion pieces of plastic weighing over 0.25 million tons, while estimates of plastic in surface waters are as high as half a million pieces per square kilometre (Law et al., 2010). A number of studies have been conducted on the influence of microplastics on various zoocoenoses and on human

Corresponding author: tomasz.mieczan@up.lublin.pl

Key words: biodiversity, eutrophication, food web, microorganisms

Edited by: Andrea Di Cesare, CNR-IRSA Verbania, Italy.

Received: 30 December 2019.

Accepted: 10 March 2020.

This work is licensed under a Creative Commons Attribution NonCommercial 4.0 License (CC BY-NC 4.0).

${ }^{\circ}$ Copyright: the Author(s), 2020

Licensee PAGEPress, Italy

J. Limnol., 2020; 79(3): 199-209

DOI: 10.4081/jlimnol.2020.1958 health (e.g. Gregory, 2009). At the same time, both Plastic (PB) and Glass Bottles (GB), as well as other waste found in water, can be colonized by various groups of microorganisms (phycoflora, bacteria, heterotrophic nanoflagellates, ciliates) and macroorganisms (rotifers, and cladocerans) forming a microcosm. Assemblages of micro- and macroorganisms colonizing submerged substrates, are complex structures including bacteria, cyanobacteria, algae, protozoa, metazoa, and macroinvertebrates. To date, most studies have investigated only the colonization of macrophytes by various groups of autotrophs and heterotrophs (Hillebrand and Sommer, 2000). Most stress the role of substrate in habitats of low nutrient availability, because macrophytes may represent a substantial nutrient source as they release nutrients (Moeller et al., 1988). Hillebrand and Sommer (2000) have shown that in eutrophic lakes, where nutrient availability is high, the differences observed between artificial (glass slides) and living substrates are not striking. However, information concerning microorganisms colonizing glass and plastic substrates is scarce and primarily pertains to peritrich ciliates (Kaur and Mehra, 1994; Madoni and Zangrossi, 2005; Oberbeckmann et al., 2016). In recent years, there has been renewed interest in the colonization and successional patterns of periphyton communities on glass slides. Boothroyd and Dickie (1989), Kaur and Mehra (1994), and Mieczan (2007) have reported the presence of similar epiphytic communities on macrophytes and on natural and artificial substrates (i.e. glass slides). These authors demonstrated that colonization by ciliates followed a similar pattern on both types of substrates, with 
dominance of Cyrtophorida and Peritrichida. Thus far, studies have primarily described periphytic ciliates from flowing waters-rivers and streams (Kaur and Mehra, 1994). However, no information is available on microand macroorganism assemblages - in particular of bacteria and flagellates - colonizing plastic and glass substrates in eutrophic retention basins. Moreover, there is a lack of research on trophic relationships between various groups of organisms colonizing these substrate types (PB vs. GB). This lack of information on the biology and ecology of organisms colonizing various substrates of anthropogenic origin prompted the present study on microcosm in a eutrophic retention reservoir. The main objective of the study was to determine: i) the taxonomic composition and/or abundance of phycoflora, bacteria, protozoa and metazoa colonizing artificial substrates of anthropogenic origin (GB and $\mathrm{PB}$ ); ii) the trophic relationships between organisms colonizing these substrates; and iii) the influence of the physicochemical properties of water on the phycoflora, bacteria, protozoa and metazoa colonizing GB and PB. As the study was carried out in a basin fed by riverine waters, it was further assumed that assemblages of micro- and macroorganisms, irrespective of the substrate type, would demonstrate greater diversity in the zone of water flowing from the river to the basin than in the rest of the basin (the bay), as according to the 'Intermediate Disturbance Hypothesis' (IDH) (Connel, 1978), minor and moderate environmental disturbances (in this case, a constant influx of water) may lead to increased biodiversity.

\section{METHODS}

\section{Study area}

The study on microcosm colonizing plastic and glass substrates was carried out in the Zemborzyce Reservoir $\left(51^{\prime} 10^{\prime \prime} 37.239^{\circ} \mathrm{N}, 22^{\prime} 31^{\prime \prime} 35.876^{\circ} \mathrm{E}\right.$, eastern Poland). This is a retention reservoir created in 1974 by damming the waters of the middle portion of the River Bystrzyca Lubelska. The surface area of the reservoir is $282 \mathrm{ha}$, the maximum length is approximately $4000 \mathrm{~m}$, and the width is $1800 \mathrm{~m}$. The mean depth of the reservoir is $1.6 \mathrm{~m}$, the maximum depth is $6 \mathrm{~m}$, and the depth at the dam is 4.0 $\mathrm{m}$. The direct vicinity of the reservoir is also diverse- to the southeast and east it is surrounded by forest, while its western shores are adjacent to arable fields and buildings.

\section{Sampling and identification of microcosm communities}

Fieldwork was done from April to November in 2017 and 2018. Abundance of bacteria, phycoflora (algae and cyanobacteria), protists (heterotrophic nanoflagellatesHNF and ciliates), and metazoans (rotifers and cladocerans) was tested once in each of 3 seasons spring (April), summer (July), and autumn (November) of 2017 and 2018. Two sampling sites in the reservoir were selected for the study of colonization of PB and GB: i) the zone of water flowing from the River Bystrzyca to the Zemborzyce Reservoir; and ii) the littoral zone in a bay located in the southeast part of the reservoir (Fig. 1). At each site, in spring, summer, and autumn, 3 PB and 3 GB were introduced and exposed for 30 days. The bottles floated on the water surface tied with a string to prevent them migrating over large distances. The water depth at both sites ranged from $40 \mathrm{~cm}$ to $50 \mathrm{~cm}$. Thus, in the period between 2017 and 2018, 36 bottles were exposed (18 at each site, including 9 GB and 9 PB). Samples for analysis of micro- and macroorganisms colonizing of $\mathrm{PB}$ and GB were obtained by placing a plastic frame measuring $5 \times 2 \mathrm{~cm}^{2}$ (total area $10 \mathrm{~cm}^{2}$ ) on the surface of a bottle and scraping off the biological material with a scalpel and a brush. Sample area and scrapings were done immediately after the bottles were pulled from the water. Each scraping was gently put into a separate plastic

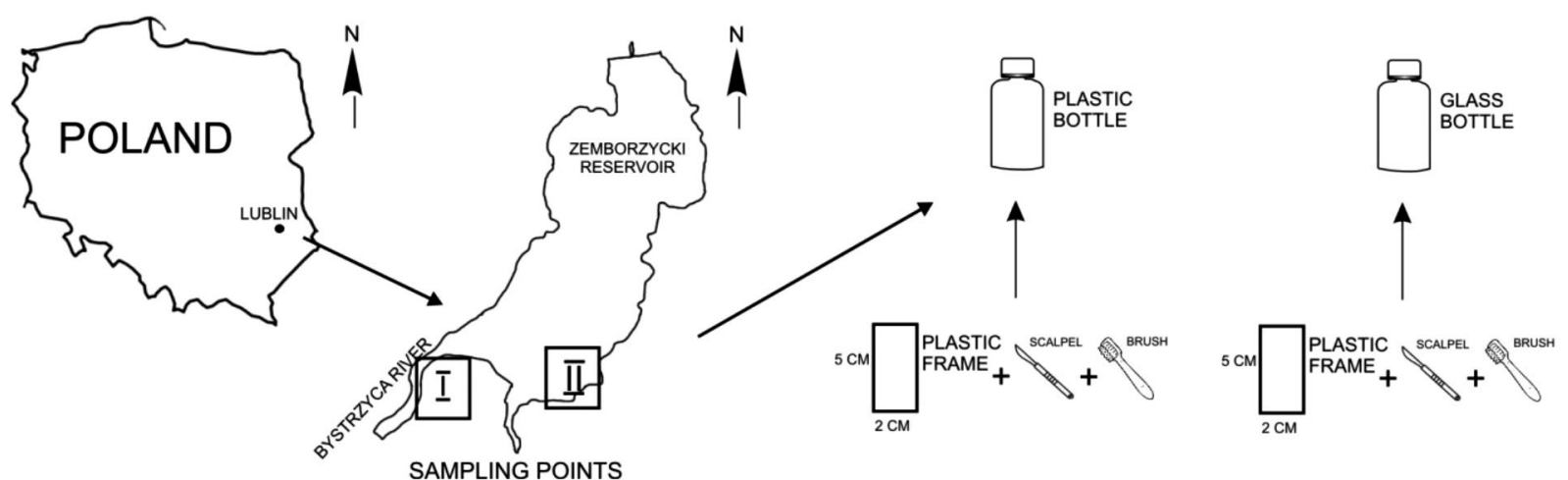

Fig. 1. Location of the investigated reservoir and study site: i) the zone of water flowing from the River Bystrzyca to the Zemborzyce Reservoir; ii) the littoral zone in a bay located in the southeast part of the reservoir. 
containers containing $150 \mathrm{~mL}$ of distilled water and mixed. Next, the suspension was filtered through a 250$\mathrm{mm}$ mesh size filter to avoid contamination of small detritus fragments or occasional invertebrates. Three samples were collected from each bottle in each season $\left(3 \times 10 \mathrm{~cm}^{2}\right)$. Then, a $50-\mathrm{mL}$ subsample was fixed with Lugol's solution for phycoflora identification, a $50-\mathrm{mL}$ for ciliates and metazoan identification and $10-\mathrm{mL}$ for bacteria and heterotrophic nanoflagellates identification. Phycoflora were identified as described by van den Hoek et al. (1995). Phycoflora biomass was calculated from the lengths and widths of algal cells using common geometric equations (Rott, 1981). The abundance and biomass of bacteria and heterotrophic flagellates were determined using DAPI (4',6-diamino-2- phenylindole) (Porter and Feig, 1980). Water samples of $10 \mathrm{~mL}$ were preserved in formaldehyde to a final concentration of $2 \%$ and kept in darkness at $4^{\circ} \mathrm{C}$. Subsamples of $2 \mathrm{~mL}$ were condensed on polycarbonate filters $(0.2 \mu \mathrm{m}$ pore diameter) rinsed twice with $5 \mathrm{~mL}$ of sterile water, dried at room temperature, and stored at $-20^{\circ} \mathrm{C}$. Whole-cell in situ hybridization of sections from the polycarbonate filters was performed with the oligonucleotide probes non 338, EUB338, ALF968, BET42a and CF319a (Pernthaler et al., 2001). Oligonucleotides labelled with the cyanine dye CY3 were synthesized by Interactivia (Germany). After FISH, the filters were air dried and mounted on glass slides in mix (Citifluor and VectaShield) amended with DAPI (final concentrations $1 \mu \mathrm{g} / \mathrm{mL}$ ). Epifluorescence microscopy (Nikon Eclipse TE-200) was used to determine the bacterial cells with the UV-2A filter for DAPI and G-2A filter for CY3. Bacteria were chosen from 5-10 randomly selected fields of each microscope slide, and 250-300 cells per slide were counted. To assess the counts of ciliates, rotifers and cladocerans, $50-\mathrm{mL}$ samples were preserved using Lugol's solution $(1 \%, \mathrm{v} / \mathrm{v})$ and settled for at least $24 \mathrm{~h}$ in plankton chambers. The ciliates and metazoa were counted and identified with an inverted microscope at 400-1000× magnification. Morphological identification of the protozoa was based mainly on the works of Foissner and Berger (1996) and Foissner et al. (1999). Metazoa were identified as described by Ruttner-Kolisko (1974) and Boxshall and Halsey (2004). Biomass of the investigated groups of organisms (phycoflora, bacteria, protozoa and metazoa) were estimated by assuming geometric shapes and converting to carbon using the following conversion factors: heterotrophic bacteria -1 $\mu \mathrm{m}^{3}=0.56 \times 10^{-6} \mu \mathrm{gC}$; flagellates $-1 \mu \mathrm{m}^{3}=0.22 \times 10^{-6}$ $\mu \mathrm{gC}$; ciliates $-1 \mu \mathrm{m}^{3}=0.11 \times 10^{-6} \mu \mathrm{gC}$ (Gilbert et al., 1998). Biomass of metazoa was estimated from the ratio of the body length and body weight of a given specimen using established mathematical formulas (Dumont et al., 1975).

\section{Physical and chemical parameters}

Water samples for physical and chemical analysis were collected from each of the two sites where bottles were exposed. Water transparency, temperature, conductivity, and $\mathrm{pH}$ were recorded in situ using a multiparametric probe (Hanna Instruments). Concentrations of total organic carbon (TOC) were measured using PASTEL UV (SECOMAM). For analysis of the concentrations of nutrients and chlorophyll $a$, water was filtered onto GF/C filters. Chlorophyll $a$ was extracted overnight in $90 \%$ acetone and its concentration was measured with a spectrophotometer (Golterman, 1969). Concentrations of total phosphorous (TP) were determined by spectrophotometry using ammonium heptamolybdate. Concentrations of $\mathrm{N}^{-\mathrm{NH}_{4}}$ were determined by the Nessler method, and $\mathrm{N}-\mathrm{NO}_{3}$ concentrations using colorimetry with brucine (Hermanowicz et al., 1976). The concentration of total nitrogen $\left(\mathrm{N}_{\text {tot }}\right)$ was determined according to DIN EN ISO 29441.

\section{Data analyses}

The effect of time and the experimental variants (PB vs. GB) on the abundance of microcosm communities was verified by analysis of variance. The significance level was set at $\mathrm{P}<0.05$. The analysis was performed using STATISTICA 7.0 software. The ordination analyses were performed in CANOCO 4.5. The proportion of variance explained by the environmental variables was quantified using variance partitioning. The length of the variability gradients of the microcosm communities was $<2$ standard deviations. Principal Component Analysis (PCA) was performed to confirm the effect of substrate on microbial communities. Redundancy Analysis (RDA) was used to explore the relationships between the density of microand macroorganisms on PB and GB and the physical and chemical parameters (Secchi disc depth, temperature, $\mathrm{pH}$, conductivity, $\mathrm{O}_{2}$, nutrients, chlorophyll $a$ and TOC) (Ter Braak and Šmilauer, 2002). Prior to PCA and RDA, the data were square root-transformed. Automatic forward selection of environmental variables (Monte Carlo permutation test) was carried out to determine the significant variables. Nonparametric Spearman rank correlation analysis was performed to determine the trophic interactions between food web components on different types of substrate.

\section{RESULTS}

\section{Species richness and abundance}

The substrate type significantly influenced the species richness of phycoflora $\left(F_{4.200}=6.33, \mathrm{P} \leq 0.05\right)$. On PB, significantly more taxa of eukaryotic algae and 
cyanobacteria were identified (11 taxa), whereas on GB only 6 algal taxa were found. Irrespective of the substrate and test site, the species richness of phycoflora was significantly higher in summer and lower in autumn $(\mathrm{P}<0.001)$. The composition and domination structure of bacteria showed only small differences among substrates $(\mathrm{P}>0.05)$. The fraction of bacterial cells hybridizing with the probe EUB338 (Bacteria) constituted from $45 \%$ to $50 \%$ of total DAPI counts. $\beta$-Proteobacteria constituting from 15 to $16 \%$. The mean share CytophagaFlavobacterium cluster in total DAPI counts ranged from $9 \%$ on GB to $13 \%$ on PB. The $\alpha$-Proteobacteria were similar in investigated substrata (7\%). ANOVA indicated that the species richness of ciliates responded to the type of substrate $\left(F_{4.100}=6.23, \mathrm{P} \leq 0.05\right.$ for all $)$ and changed over time $\left(F_{4.200}=6.41, \mathrm{P} \leq 0.001\right)$. Significantly greater species richness of ciliates (12 taxa) was found on $\mathrm{PB}$, whereas only 7 taxa of these protozoans were found on GB $(\mathrm{P} \leq 0.05)$. The number of ciliate species was significantly higher in autumn $(\mathrm{P} \leq 0.001)$. On the other hand, the substrate type was not found to significantly influence the species richness of rotifers and crustaceans $(\mathrm{P}>0.05)$. The number of rotifer and crustacean species found on PB (4 taxa) was only slightly higher than on GB (3 taxa) $(\mathrm{P} \leq 0.001)$. The highest number of small metazoa was recorded in autumn, with a slightly lower number in spring and summer, but these differences were not statistically significant $(\mathrm{P}>0.05)$.

The densities of phycoflora varied significantly with type of substrate and season $\left(F_{1-2}=281-9.44, \mathrm{P}<0.001\right.$, respectively, Tab. 1). The abundance of phycoflora ranged from 140 cells cm$~_{-2}$ in spring to 500 cells cm$~^{-2}$ in summer. The total abundance of algae and cyanobacteria was significantly higher on the surface of $\mathrm{PB}$ than on GB at site 1 , while at site 2 the abundance was very similar $(\mathrm{P}>0.05)$. On both substrata, 3 taxonomic groups of algae were identified: diatoms, cyanophytes, and chlorophytes. Diatoms and cyanophytes (Microcystis sp. and Oscillatoria sp.) were the dominant group on both substrates. The proportions of these algae varied from $46 \%$ (spring) to $52 \%$ (summer) on $\mathrm{PB}$ and from $21 \%$ (spring) to $35 \%$ (summer and autumn) on GB (Fig. 2A). For bacteria, the $p$-values indicated a strong effect of the time of collection, substrate and sites on their abundance $\left(F_{2-7}=14.97-9.43, \mathrm{P}<0.001\right)$ (Tab. 1). Irrespective of the substrate, the abundance of bacteria exhibited seasonal variability. The lowest bacterial count was noted in spring and autumn $\left(0.3-0.4 \times 10^{4}\right.$ cells $\left.\mathrm{cm}^{-2}\right)$ and the highest in summer $\left(0.5 \times 10^{4}\right.$ cells $\left.\mathrm{cm}^{-2}\right)$. The total abundance of bacteria was significantly higher on $\mathrm{PB}$ $(\mathrm{P}<0.001)$. The densities of heterotrophic nanoflagellates varied significantly with type of substrate $\left(F_{2}=18.97\right.$, $\mathrm{P}<0.001$ ) (Tab. 1). Abundance of heterotrophic flagellates was significantly higher on $\mathrm{PB}(\mathrm{P}<0.001)$, with $0.3 \times 10^{4}$ cells $\mathrm{cm}^{-2}$, and exhibited seasonal variability on both $\mathrm{PB}$ and GB $\left(F_{2}=9.43, \mathrm{P}=0.034\right)$. For ciliates, the $p$-values indicated a strong effect of $\mathrm{PB}$ and GB $\left(F_{2}=15.97\right.$, $\mathrm{P}<0.001)$, the time of collection and site $\left(F_{2}=16.23, \mathrm{P}<0.05\right)$ on their abundances (Tab. 1). Irrespective of the substrate, the abundance of these microorganisms was higher in spring and autumn than in summer $(\mathrm{P}<0.001)$. The mean abundance of ciliates $\left(33\right.$ cells $\left.\mathrm{cm}^{-2}\right)$ was significantly higher on PB than on GB ( 22 cells cm$\left.~^{-2}\right)(\mathrm{P}<0.05)$. The dominance of taxa was markedly varied between substrates. PB were primarily colonized by bacterivorous Epistylis plicatilis and Carchesium polypinum, omnivorous Vorticella campanula, while the most common taxa on GB were bacterivorous Epistylis plicatilis and omnivorous Metopus sp. (Fig. 2B). Furthermore, the trophic structure of ciliates demonstrated seasonal variability. In spring, the substrates were colonized by bacterivorous ciliates (Epistylis plicatilis, Euplotes octocarinatus), whereas in the following seasons there was a larger share of omnivorous species (Chilodonella uncinata, Opercularia articulate, Metopus sp., Loxodes sp.). The densities of metazoa varied significantly with time (rotifers, $F_{2}=17.32, \mathrm{P}<0.001$ ), site and type of substrate (rotifes and cladocerans, $F_{2-1}=50.75$ $27.85, \mathrm{P}<0.001$, respectively) (Tab. 1). At both sites the abundance of metazoa was significantly higher on GB (mean: 16 individuals $\mathrm{cm}^{-2}$ ) than on PB (mean: 7 individuals $\left.\mathrm{cm}^{-2}\right)(\mathrm{P}<0.001)$. Small metazoans were most abundant in spring and/or autumn on both PB and GB, but irrespective of the substrate type, omnivorous Lecane pumila, Lecane flexis and Lecane lunaris had the highest share of the total abundance (Fig. 2C).

\section{Biomass of food web components}

Irrespective of the substrate type, phycoflora had the largest share of the total microbial biomass (37-60\%) in all seasons. Rotifers were the second largest group of microorganisms (20-25\% of the total microbial biomass). Bacteria constituted $9-11 \%$ of the total microbial biomass. The biomass of heterotrophic flagellates and ciliates was the lowest, between $2 \%$ and $12 \%$. The biomass of all analysed groups of organisms was significantly higher on $\mathrm{PB}\left(F_{2}=61.14, \mathrm{P}<0.001\right)$. The biomass of heterotrophic bacteria was very low in spring and reached its maximum in autumn. The biomass of flagellates was highest in summer, while that of ciliates and metazoans was highest in spring and autumn (Fig. 3).

\section{Physical and chemical parameters}

Irrespective of the test site, the physicochemical properties of the water exhibited significant seasonal variability $(\mathrm{P}<0.001)$. The Secchi disc visibility ranged from 0.13 (July) to $0.45 \mathrm{~m}$ (November). The concentration of dissolved oxygen in the water always exceeded $9.0 \mathrm{mg} \mathrm{L}^{-1}$, while that of chlorophyll $a$ was 
relatively high, ranging from $82.11-86.32$ (April) to 290.11-300.99 $\mu \mathrm{g} \mathrm{L}^{-1}$ (July). The TOC concentration did not differ significantly between seasons, and ranged from 3.2 to $12.7 \mathrm{mg} \mathrm{C} \mathrm{L}^{-1}(\mathrm{P}>0.05)$. TP concentrations ranged from $0.139 \mathrm{mg} \mathrm{L}^{-1}$ in April to $0.268 \mathrm{mg} \mathrm{L}^{-1}$ in July. The concentration of ammonium nitrogen was highest in

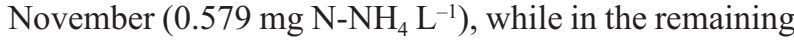
seasons it ranged from 0.070 to $0.105 \mathrm{mg} \mathrm{N}-\mathrm{NH}_{4} \mathrm{~L}^{-1}$. The nitrate nitrogen concentration was relatively low, at $0.015-0.468 \mathrm{mg} \mathrm{N}^{-\mathrm{NO}_{3}} \mathrm{~L}^{-1}$. The total nitrogen concentration exhibited seasonal variability, with the highest values noted in July $\left(2.2 \mathrm{mg} \mathrm{N} \mathrm{L}^{-1}\right)$ and the lowest in November (1.46 $\left.\mathrm{mg} \mathrm{N} \mathrm{L}^{-1}\right)$ (Tab. 2).

\section{The effect of physical and chemical parameters on microcosm}

In PCA, axis $1(\lambda=0.892)$ and axis $2(\lambda=0.061)$ explained $89 \%$ of the total variance in microcosm communities. The first 2 axes showed a clear separation of microcosm communities on the substrates (Fig. 4 A,B). RDA was performed to determine the direct relationships between the abundance of taxonomic groups of microcosm and the physical and chemical parameters.

Tab. 1. Results of main effects ANOVA on density of phycoflora, bacteria, heterotrophic nanoflagellates, ciliates, rotifers and cladocerans testing for the effect of the substrate, time (season) and the site (significant P values in bold).

\begin{tabular}{|c|c|c|c|c|c|}
\hline & df & SS & MS & F & $\mathbf{P}$ \\
\hline \multicolumn{6}{|l|}{ Phycoflora } \\
\hline Intercept & 1 & 490.20 & 490.20 & 965.00 & $<0.001$ \\
\hline Substrate (S) & 1 & 144.20 & 144.20 & 281.00 & $<0.001$ \\
\hline Season (Se) & 2 & 21.41 & 13.51 & 9.44 & 0.045 \\
\hline Site (Si) & 2 & 11.41 & 8.21 & 6.44 & 0.245 \\
\hline $\mathrm{S} \times \mathrm{Se}$ & 2 & 13.11 & 15.11 & 12.37 & 0.047 \\
\hline $\mathrm{S} \times \mathrm{Se} \times \mathrm{Si}$ & 1 & 124.20 & 112.20 & 81.00 & $<0.001$ \\
\hline \multicolumn{6}{|l|}{ Bacteria } \\
\hline Intercept & 2 & 80.02 & 80.01 & 90.45 & $<0.001$ \\
\hline Substrate (S) & 2 & 21.00 & 12.04 & 14.97 & $<0.001$ \\
\hline Season $(\mathrm{Se})$ & 7 & 21.43 & 15.51 & 9.43 & 0.050 \\
\hline Site $(\mathrm{Si})$ & 2 & 22.00 & 12.04 & 14.97 & $<0.001$ \\
\hline $\mathrm{S} \times \mathrm{Se}$ & 2 & 2.18 & 9.12 & 17.35 & 0.037 \\
\hline $\mathrm{S} \times \mathrm{Se} \times \mathrm{Si}$ & 2 & 12.11 & 12.23 & 11.37 & 0.147 \\
\hline \multicolumn{6}{|c|}{ Heterotrophic flagellates } \\
\hline Intercept & 2 & 70.02 & 60.01 & 90.28 & $<0.001$ \\
\hline Substrate (S) & 2 & 20.00 & 11.03 & 18.97 & $<0.001$ \\
\hline Season $(\mathrm{Se})$ & 6 & 21.41 & 13.51 & 9.43 & 0.037 \\
\hline Site $(\mathrm{Si})$ & 2 & 14.00 & 12.04 & 14.97 & 0.072 \\
\hline $\mathrm{S} x \mathrm{Se}$ & 2 & 3.18 & 12.12 & 17.35 & 0.034 \\
\hline $\mathrm{S} \times \mathrm{Se} \times \mathrm{Si}$ & 2 & 16.11 & 17.23 & 8.23 & 0.147 \\
\hline \multicolumn{6}{|c|}{ Ciliates } \\
\hline Intercept & 2 & 80.02 & 80.01 & 127.23 & $<0.001$ \\
\hline Substrate (S) & 2 & 21.00 & 9.03 & 15.97 & $<0.001$ \\
\hline Season $(\mathrm{Se})$ & 7 & 0.46 & 0.54 & 7.43 & 0.055 \\
\hline Site $(\mathrm{Si})$ & 2 & 30.02 & 21.23 & 16.23 & $<0.001$ \\
\hline $\mathrm{S} \times \mathrm{Se}$ & 2 & 2.18 & 10.12 & 16.23 & 0.035 \\
\hline $\mathrm{S} \times \mathrm{Se} \times \mathrm{Si}$ & 2 & 71.01 & 60.01 & 98.23 & $<0.001$ \\
\hline \multicolumn{6}{|l|}{ Rotifers } \\
\hline Intercept & 1 & 27.11 & 26.22 & 68.12 & $<0.001$ \\
\hline Substrate (S) & 2 & 5.92 & 2.95 & 50.75 & $<0.001$ \\
\hline Season $(\mathrm{Se})$ & 6 & 8.81 & 11.11 & 17.32 & 0.050 \\
\hline Site $(\mathrm{Si})$ & 2 & 5.92 & 2.95 & 50.75 & $<0.001$ \\
\hline $\mathrm{S} \times \mathrm{Se}$ & 2 & 0.57 & 3.31 & 7.19 & 0.057 \\
\hline $\mathrm{S} \times \mathrm{Se} \times \mathrm{Si}$ & 2 & 5.92 & 4.95 & 9.75 & 0.041 \\
\hline \multicolumn{6}{|l|}{ Cladocerans } \\
\hline Intercept & 1 & 27.11 & 26.22 & 68.12 & $<0.001$ \\
\hline Substrate (S) & 1 & 53.24 & 51.36 & 27.85 & $<0.001$ \\
\hline Season $(\mathrm{Se})$ & 2 & 26.11 & 19.32 & 55.81 & 0.087 \\
\hline Site $(\mathrm{Si})$ & 1 & 43.24 & 25.36 & 27.85 & $<0.001$ \\
\hline $\mathrm{S} \times \mathrm{Se}$ & 8 & 9.61 & 11.11 & 2.51 & 0.092 \\
\hline $\mathrm{S} \times \mathrm{Se} \times \mathrm{Si}$ & 2 & 28.14 & 20.12 & 54.32 & 0.062 \\
\hline
\end{tabular}


A) Phycoflora

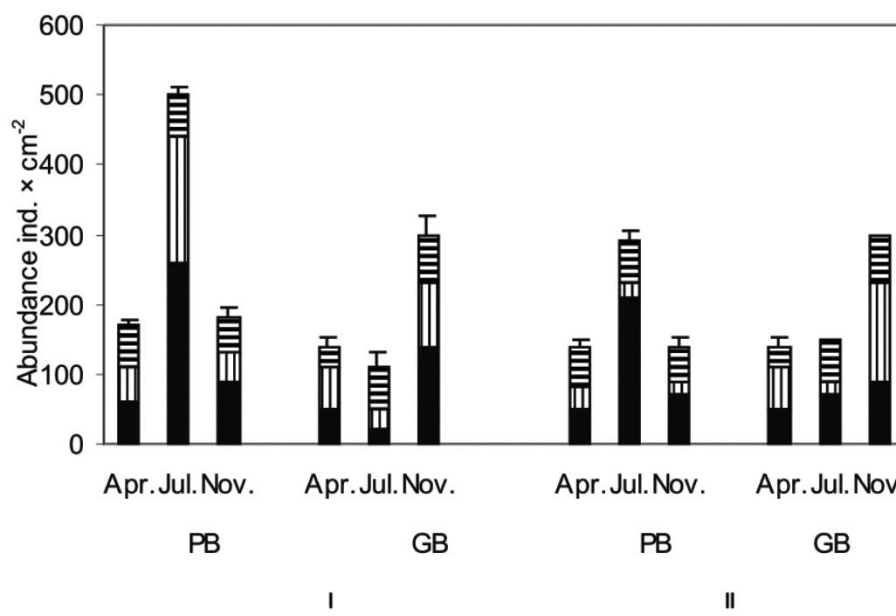

B) Ciliates

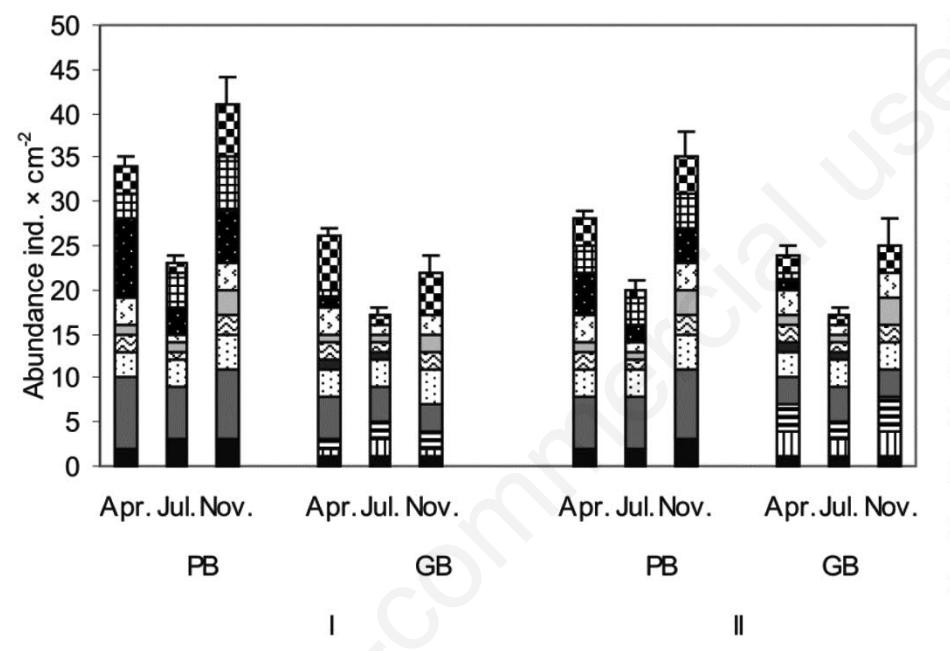

C) Rotifers and Cladocerans

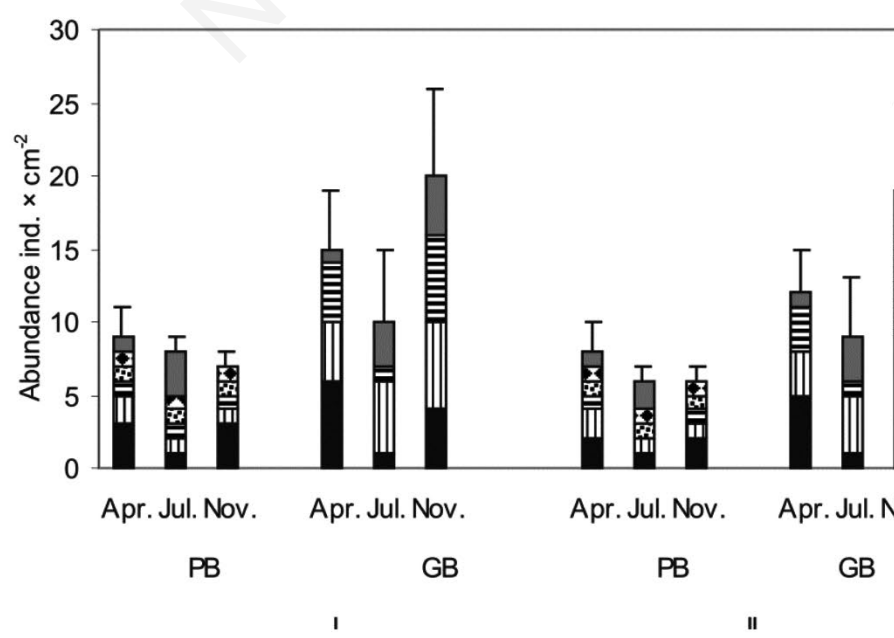

$\boxminus$ Chlorophytes

(1) Diatoms

- Cyanophyes
ఐ Vorticella companula

$\boxplus$ Stylonychia mytilus-

complex

- Euplotes octocarinatus

그abdostyla inclinans

$\square$ Thuricola kellicottiana

$\checkmark$ Opercularia articulata

- Lacrymaria olor

$\square$ Carchesium polypinum

$\square$ Epistylis plicatilis

$\boxminus$ Metopus $s p$.

पL Loxodes sp.

- Chilodonella uncinata 
RDA showed that the physical and chemical parameters played a similar role as driving forces of colonization on both PB and GB. In the case of organisms colonizing PB, the variables together explained $79.3 \%$ of the total variance The most significant of these were TOC $(\lambda=0.10$, $F=12.52, \mathrm{P}=0.002), \mathrm{N}_{-} \mathrm{NO}_{3}(\lambda=0.70, F=54.61, \mathrm{P}=0.001)$, and $\mathrm{pH}(\lambda=0.03, F=5.31, \mathrm{P}=0.001)$. RDA of the distribution of microcosm communities and physical and chemical parameters suggested that the abundances of bacteria and phycoflora showed a strong dependence on the concentrations of $\mathrm{N}-\mathrm{NO}_{3}$ and TOC and $\mathrm{pH}$, as the rising gradient of these variables correlated with a reduction in abundances of phycoflora and bacteria on GB (Fig. 5A-B). On the other hand, TOC was identified as the factor with the greatest impact on the formation of microcosm on GB (all variables explained $68 \%$ of the total variance) $(\lambda=0.23, F=27.11, \mathrm{P}=0.001)$, followed by $\mathrm{N}_{-\mathrm{NO}_{3}}(\lambda=0.659, F=30.21, \mathrm{P}=0.002)$ and $\mathrm{N}-\mathrm{NH}_{4}(\lambda=0.04$, $F=5.81, \mathrm{P}=0.003)$. In the RDA, the abundance of bacteria and rotifers showed a positive relationship with $\mathrm{N}-\mathrm{NH}_{4}$, while that of protists and algae showed a negative relationship with $\mathrm{N}-\mathrm{NO}_{3}$ and TOC (Fig. 5A-B).

Tab. 2. Physical and chemical parameters of water in Zemborzycki reservoir in 2017-2018.

\begin{tabular}{|c|c|c|c|c|c|c|c|c|c|c|c|c|c|}
\hline & \multirow[t]{3}{*}{ Parameters } & \multicolumn{6}{|c|}{ Site I } & \multicolumn{6}{|c|}{ Site II } \\
\hline & & \multicolumn{2}{|c|}{ April } & \multicolumn{2}{|c|}{ July } & \multicolumn{2}{|c|}{ November } & \multicolumn{2}{|c|}{ April } & \multicolumn{2}{|c|}{ July } & \multicolumn{2}{|c|}{ November } \\
\hline & & mean & $\pm \mathrm{SD}$ & mean & $\pm \mathrm{SD}$ & mean & $\pm \mathrm{SD}$ & mean & $\pm \mathrm{SD}$ & mean & $\pm \mathrm{SD}$ & mean & $\pm \mathrm{SD}$ \\
\hline Secchi disc depth & $(\mathrm{m})$ & 0.31 & \pm 0.03 & 0.13 & \pm 0.01 & 0.35 & \pm 0.06 & 0.33 & \pm 0.02 & 0.24 & \pm 0.01 & 0.45 & \pm 0.06 \\
\hline Temp. & ${ }^{\circ} \mathrm{C}$ & 21.72 & \pm 1.3 & 25.65 & \pm 1.6 & 14.38 & \pm 2.6 & 21.12 & \pm 1.3 & 25.15 & \pm 1.4 & 15.11 & \pm 2.2 \\
\hline $\mathrm{pH}$ & & 8.54 & \pm 1.1 & 8.07 & \pm 1.2 & 8.37 & \pm 1.1 & 8.44 & \pm 1.1 & 8.07 & \pm 1.2 & 8.37 & \pm 1.1 \\
\hline Conductivity & $\left(\mu \mathrm{S} \mathrm{cm}^{-1}\right)$ & 431 & \pm 12 & 279 & \pm 8 & 345 & \pm 14 & 436 & \pm 11 & 279 & \pm 8 & 360 & \pm 15 \\
\hline $\mathrm{O}_{2}$ & $\left(\mathrm{mg} \mathrm{O}_{2} \mathrm{~L}^{-1}\right)$ & 9.25 & \pm 1.1 & 18.86 & \pm 1.1 & 15.4 & \pm 1.2 & 9.1 & \pm 2.1 & 19.11 & \pm 1.1 & 14.6 & \pm 1.2 \\
\hline $\mathrm{N}_{\text {tot }}$ & $\left(\mathrm{mg} \mathrm{N} \mathrm{L}^{-1}\right)$ & 2.1 & \pm 0.023 & 2.2 & \pm 0.021 & 1.46 & \pm 0.023 & 1.1 & \pm 0.023 & 2.2 & \pm 0.021 & 1.46 & \pm 0.023 \\
\hline $\mathrm{N}-\mathrm{NH}_{4}^{+}$ & $\left(\mathrm{mg} \mathrm{N} \mathrm{L}^{-1}\right)$ & 0.105 & \pm 0.002 & 0.070 & \pm 0.001 & 0.579 & \pm 0.003 & 0.111 & \pm 0.002 & 0.070 & \pm 0.001 & 0.579 & \pm 0.002 \\
\hline $\mathrm{N}-\mathrm{NO}_{3}$ & $\left(\mathrm{mg} \mathrm{N} \mathrm{L}^{-1}\right)$ & 0.458 & \pm 0.003 & 0.044 & \pm 0.003 & 0.015 & \pm 0.002 & 0.468 & \pm 0.003 & 0.044 & \pm 0.003 & 0.015 & \pm 0.002 \\
\hline $\mathrm{P}-\mathrm{PO}_{4}{ }^{3-}$ & $\left(\mathrm{mg} \mathrm{PO}_{4}{ }^{3-} \mathrm{L}^{-1}\right)$ & 0.053 & \pm 0.003 & 0.006 & \pm 0.001 & 0.005 & \pm 0.002 & 0.056 & \pm 0.003 & 0.006 & \pm 0.001 & 0.005 & \pm 0.002 \\
\hline $\mathrm{P}_{\text {tot }}$ & $\left(\mathrm{mg} \mathrm{P} \mathrm{L}^{-1}\right)$ & 0.139 & \pm 0.004 & 0.268 & \pm 0.004 & 0.171 & \pm 0.003 & 0.139 & \pm 0.003 & 0.268 & \pm 0.004 & 0.161 & \pm 0.002 \\
\hline Chlorophyl- $a$ & $\left(\mu \mathrm{g} \mathrm{L}^{-1}\right)$ & 86.32 & \pm 8.3 & 300.99 & \pm 11.3 & 165.25 & \pm 7.2 & 82.11 & \pm 7.6 & 290.11 & \pm 10.1 & 172.25 & \pm 6.3 \\
\hline TOC & $\left(\mathrm{mg} \mathrm{C} \mathrm{L} \mathrm{L}^{-1}\right)$ & 9.2 & \pm 1.1 & 7.8 & \pm 0.52 & 12.7 & \pm 1.0 & 6.4 & \pm 1.1 & 4.2 & \pm 0.52 & 3.2 & \pm 1.0 \\
\hline
\end{tabular}

Site I, zone of water flowing from the river to reservoir; Site II, littoral zone.

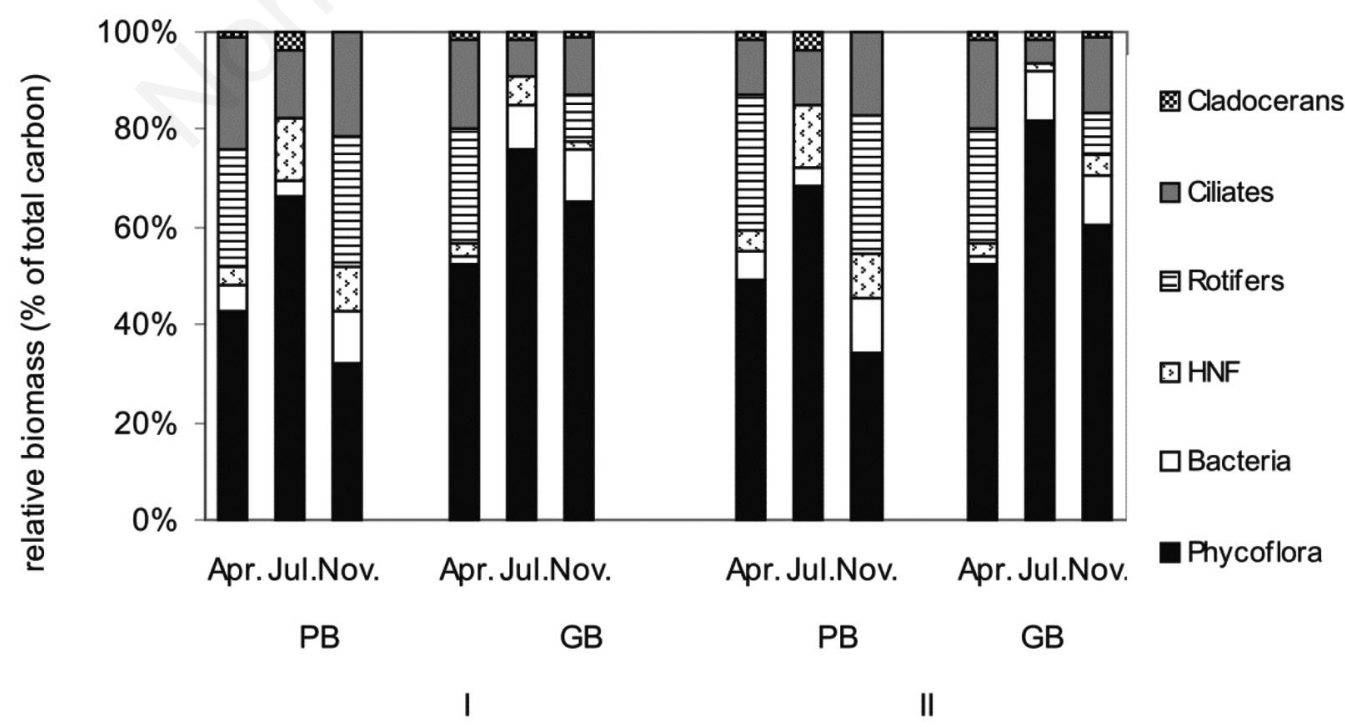

Fig. 3. Percentage share of phycoflora, bacteria, heterotrophic flagellates, ciliates, rotifers and crustaceans on plastic and glass bottles; PB, plastic bottles; GB, glass bottles; site I, zone of water flowing from the river to the reservoir; site II, littoral zone. 


\section{Relationship between food web components}

Generally, the abundance of phycoflora was correlated with the abundance of ciliates and small metazoans (from $r=-0.46, \mathrm{P} \leq 0.05$ to $r=-0.77, \mathrm{P} \leq 0.01)$. However, the number of significant correlations between the main groups of organisms forming the food webs varied between substrates. On PB, the correlations between the food web components were stronger. Abundance of phycoflora correlated negatively with abundance of ciliates $(r=-0.76, \mathrm{P} \leq 0.01)$ and metazoa $(r=-0.64, \mathrm{P} \leq 0.01)$. The abundance of bacteria and heterotrophic nanoflagellates correlated positively with the density of ciliates (from $r=0.48$ to $r=0.55, \mathrm{P} \leq 0.05$ ). On $\mathrm{GB}$, there was a significant and positive correlation between the density of ciliates and rotifers $(r=0.71, \mathrm{P} \leq 0.01)$. The
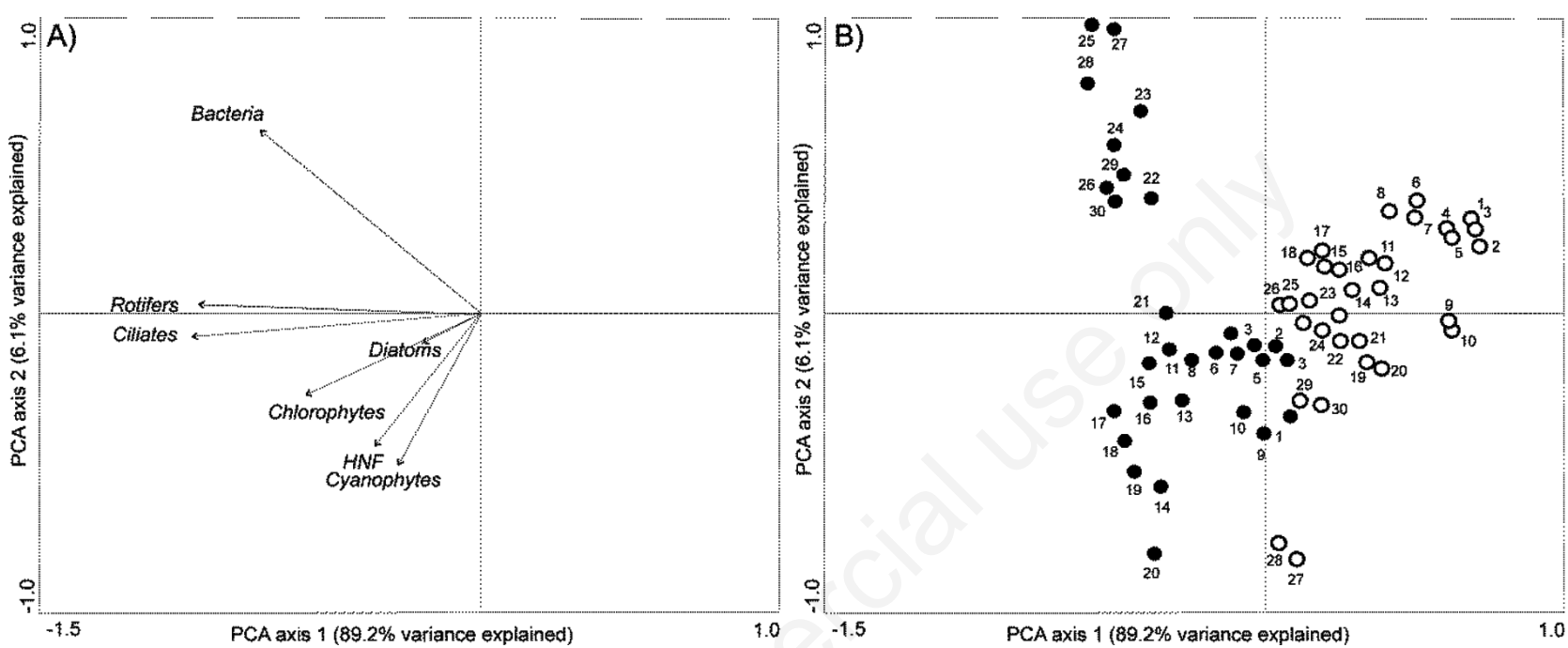

Fig. 4. Principal component analysis (PCA) biplots for axes 1 and 2 showing microcosm communities (A), and substrates (B); ○, glass bottles; $\bullet$, plastic bottles.
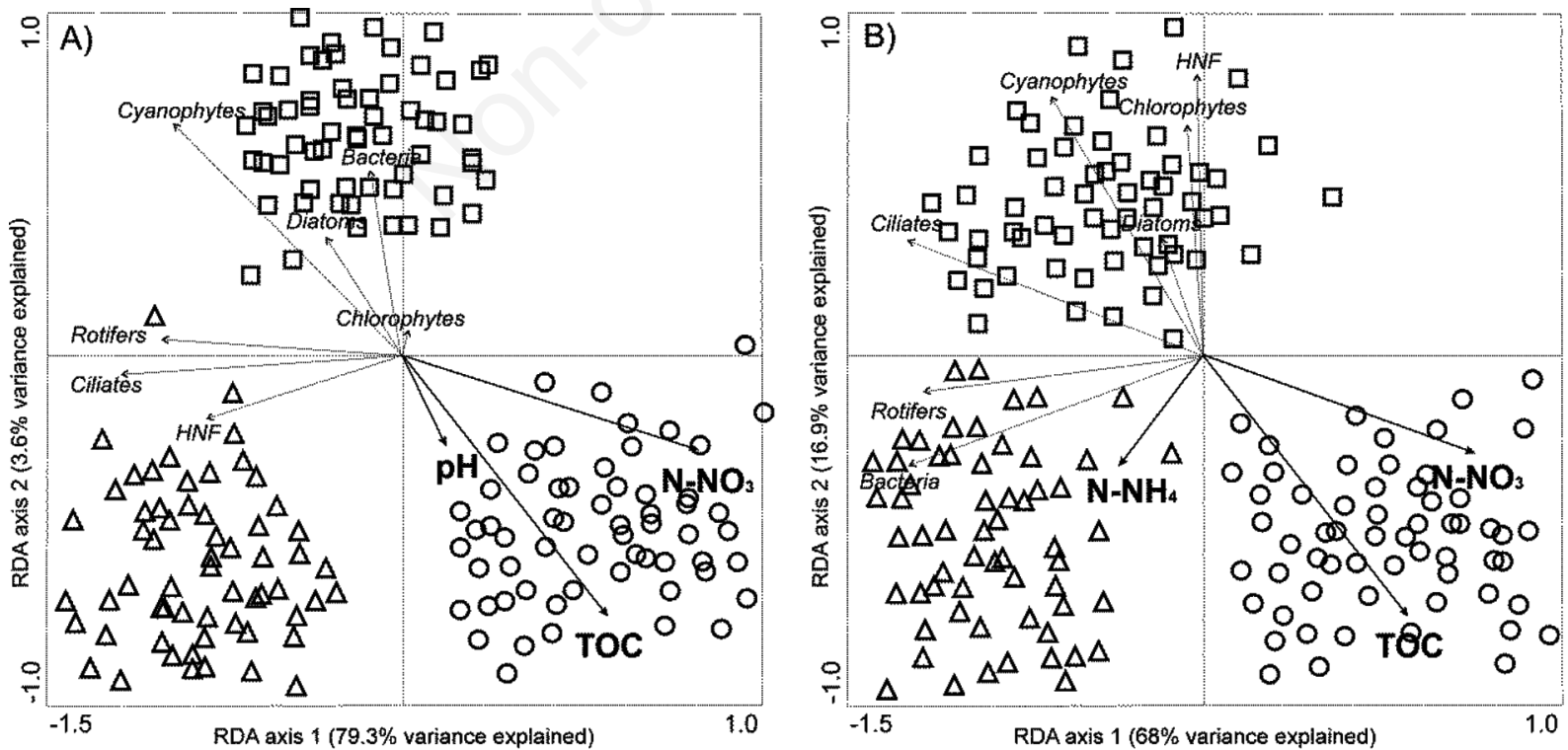

Fig. 5. Redundancy analysis (RDA) triplots showing communities, physical and chemical parameters, and samples collected on plastic bottles (A) and glass bottles (B). Solid arrows indicate significant parameters in the Monte Carlo permutation test at $\mathrm{P}<0.05$; $\bigcirc$, spring samples; $\square$, summer samples; $\Delta$, autumn samples. 
density of ciliates correlated positively with the abundance of phycoflora $(r=0.69, \mathrm{P} \leq 0.01)$ and negatively with bacterial density $(r=-0.43, \mathrm{P} \leq 0.05)$.

\section{DISCUSSION}

The species richness of micro- and macroorganisms colonizing the exposed substrates was highest on PB and exhibited seasonal variability. In late summer and in autumn, cyanobacteria dominated on PB and formed a 'filamentous' microcosm. These organisms are usually an important component of phycoflora communities at high phosphorous levels (Gaiser et al., 2006). This type of microcosm appears to create more microniches, owing to which it is more readily colonized by bacteria, protozoans, and small metazoa. In contrast, a shell-like microcosm was found on GB, with a predominance of diatoms. Similar seasonal variability has been observed in assemblages of periphytic microorganisms on macrophytes and glass slides in shallow lakes (Mieczan, 2007). In addition, higher species richness was observed in the zone of water flowing from the river to the basin. It appears that moderate disturbances may have occurred at this site, causing an increase in the species diversity of the microcosm, which is in line with the IDH theory (Connel, 1978). Furthermore, riverine waters may have disturbed the upper layer of the bottom sediments and contributed to the colonization of the exposed substrates by various species of micro- and macroorganisms present in the sediment. An increase in the number of typical benthic taxa was observed on the surface of both PB and GB at site 1 , which may indicate a strong influence of river water on the structure of the bottom sediments of the basin. According to Napiórkowski et al. (2019), river water flowing into a basin causes minor disturbances and stimulates the development of rotifers and crustaceans, in accordance with the Intermediate Disturbance Hypothesis. Moreover, the zone of water flowing from the river to the basin functions as an ecotone, i.e. a contact zone between two types of ecosystems, flowing water and standing water. In this type of zone the species richness and abundance of various groups of organisms frequently increase. The present study suggests that a portion of the microorganisms forming the microcosm may have utilized the surface of the bottles as a potential refugium to escape from the pressure of planktonic rotifers and crustaceans. This hypothesis is supported by the marked increase in abundance of the ciliate E. plicatilis on the surface of PB and GB, particularly in spring and autumn. Microscopic observations showed that this species was abundant in the pelagic zone, but at the same time it intensively colonized the bottles, producing long stalks. The formation of these structures is likely associated with considerable energy expenditure; however, the transfer from a free-swimming to a sedentary lifestyle probably favours avoidance of predator pressure in the water column. This type of defence has been observed in other groups of planktonic organisms as well (Bickel et al., 2012). In the present study, the species number of rotifers was higher than that reported by Bołtruszko (2011). In contrast, Ejsmont-Karabin and Karpowicz (2019) recorded higher species richness of sedentary rotifers, but on natural substrates (e.g. mussel shells).

The abundance of individual groups of microorganisms was typically higher on the PB surface. The numbers of bacteria on both substrates were similar to those recorded in sandy sediments in a eutrophic lake (Kalinowska et al., 2012). To date, there is no information available on the numbers, biomass, and role of flagellates on PB and GB. In the present study, the numbers of flagellates on these substrates were $0.3-0.4 \times 10^{3}$ cells $\mathrm{cm}^{-2}$. In the hydroarenal zone of a eutrophic lake, the number of flagellates ranged between 4.3 and $78.2 \times 10^{3}$ cells cm$~^{-2}$ (Kalinowska et al., 2012). In contrast, Mieczan and Rudyk-Leuska (2019) found $0.2-0.4 \times 10^{3}$ cells cm$^{-2}$ of these microorganisms on the shell surface of the mussel Unio tumidus. The abundance of ciliates colonizing the surface of bottles was similar to that noted on natural and artificial substrates in eutrophic lakes (Mieczan, 2006). On the other hand, in a study on periphytic ciliates on glass substrates in a eutrophic lake in Croatia, the abundance of these microorganisms ranged between 40 and 2400 individuals $\mathrm{cm}^{-2}$ (Primc-Habdija et al., 1997). However, in dystrophic lakes in Germany, the counts of ciliates on glass slides did not exceed 30 individuals $\mathrm{cm}^{-}$ ${ }^{2}$ (Strüder-Kypke, 1999). The lower abundances of ciliates on GB may stem from the fact that the substrate was intensely colonized throughout the study period by rotifers and crustaceans, which were able to control the abundance of protozoans. On both PB and GB, the highest abundance of ciliates was recorded in autumn, while the lowest abundance was observed in summer. The increase in the abundance of ciliates in autumn could have been due to favourable nutritional conditions for this group of microorganisms. In this season, the water of the littoral zone had a considerable amount of organic matter. Higher abundance of ciliates in this period may also have stemmed from the marked increase in their abundance in the pelagic zone. The study by Mieczan and RudykLeuska (2019) indeed indicates the periodic appearance of planktonic species in an assemblage of typical sedentary organisms, including biofilm or periphyton. On the other hand, the low abundances of ciliates in summer could have resulted from their consumption by organisms of higher trophic levels. As demonstrated by Carrias et al. (1998), metazoans control the abundance of protozoans, particularly in summer. Irrespective of the substrate type, the trophic structure of ciliates was dominated by 
omnivorous and bacterivorous species. A high count of omnivorous ciliates in freshwater basins has also been observed by other authors (Beaver and Crisman, 1989). Research conducted on ciliates in eutrophic lakes has demonstrated that in the early stages of colonization, natural and artificial substrates were dominated by bacterivorous species, whereas after approximately 2 weeks of exposure, the contribution of algivorous taxa increased as well (Mieczan, 2006). Beaker (1984) found that bacteria appear after just $4 \mathrm{~h}$ of substrate exposure. Such early appearance of bacterivores may be due to favourable feeding conditions. Algivorous species were the least abundant on the substrates. The low abundance of algivorous ciliates could have been caused by difficulties in obtaining food, as the substrate was primarily colonized by filamentous and colonial forms poorly available to ciliates. Apart from the substrate itself, the physicochemical properties of the water at the sampling sites were also of particular importance. In general, the abundance of microorganisms, rotifers and crustaceans coincided with higher concentrations of organic matter and nutrients. Similar relationships have been observed in assemblages of planktonic microorganisms (Andersen et al., 2013). Water temperature was another significant factor. As demonstrated by Finlay (1982), the growth and reproduction of microorganisms are strongly correlated with temperature. This factor furthermore influences the reproduction rate of bacteria, which are the major source of food for heterotrophic organisms. This is confirmed by the transformation of the trophic structure of protozoans. In spring, bacterivorous, omnivorous and predatory species were predominant on the surface of both PB and $\mathrm{GB}$, while in summer there was an increase in algivorous species, and the abundance of bacterivorous ciliates increased in autumn. The increase in the share of bacterivorous species in autumn probably coincided with favourable feeding conditions resulting from the high content of TOC in the water. In the case of both substrates, the abundance of ciliates was strongly correlated with electrolytic conductivity and the content of TOC in the water. Other studies (Mieczan, 2006) have also found an increase in the abundance of ciliates on natural and artificial substrates as these factors increased. Significant positive correlations between TOC content in the water and the abundance of ciliates on the stems of $P$. australis and glass plates have also been identified in shallow lakes (Mieczan, 2007).

\section{CONCLUSIONS}

In summary, both species richness and the abundance of micro- and macroorganisms were determined by the type of substrate colonized as well as by the physicochemical properties of the water (primarily the content of total organic carbon and nitrate nitrogen). The flow of water from the river into the reservoir (site 1) may have stimulated microcosm development in accordance with the IDH theory. The season also influenced the abundance and trophic structure of organisms colonizing the substrates. In spring, the substrates were intensively colonized by bacterivorous ciliates, whereas in the following seasons the contribution of omnivorous ciliates and rotifers species was higher. The number of significant correlations between the main groups of organisms forming the microcosms food web varied between the substrates, and on plastic bottles the relations between food web components were stronger. This may indicate that the accumulation of various types of anthropogenic waste, in the present case GB and PB, may influence the matter and energy cycle, including the carbon cycle, in various microhabitats of aquatic ecosystems. Therefore, future research should focus on the influence of microplastic particles on the functioning of trophic networks in microbial assemblages colonizing various types of substrates submerged in water.

\section{REFERENCES}

Andersen R, Wells C, Macrae M, Price J, 2013. Nutrient mineralization and microbial functional diversity in a restored bog approach natural conditions 10 years post restoration. Soil Biol. Biochem. 64:37-47.

Beaker JH, 1984. Factors affecting the bacterial colonization of various surfaces in a river. Can. J. Microbiol. 30:511-516.

Beaver JR, Crisman TL, 1989. The role of ciliated protozoa in pelagic freshwater ecosystems. Microb. Ecol.17:11-136.

Bickel SL, Tang KW, Grossart HP, 2012. Ciliate epibionts associated with crustacean zooplankton in German lakes: distribution, motility, and bacterivory. Front. Microbiol. 3:243.

Bołtruszko J., 2011. Epizoic communities of Rotifera on freshwater bivalves. Oceanolog. Hydrobiol. Stud. 39:75-82.

Boothroyd IKG, Dickie BN, 1989. Macroinvertebrates colonisation of perspex artifical substrates for use in biomonitoring studies. New Zealand J. Marine Freshw. Res. 23:467-478

Boxshall GA, Halsey SH, 2004. An introduction to copepod diversity. Royal Society, Andover, UK.

Carrias JF, Amblard C, Beurdier G, 1998. Seasonal dynamics and vertical distribution of planktonic ciliates and their relationship to microbial food resources in the oligomesotrophic Lake Pavin. Arch. Hydrobiol. 143:227-255.

Connel JH, 1978. Diversity in tropical rain forest and coral reefs. Science 199:1302-1310.

Córaz A, Echevarria F, Gonzalez-Gordillo IJ, Irigoien X, Ubenda $\mathrm{B}$, Hornàndez-León S, 2014. Plastic debris in the open ocean. Proc. Nat. Acad. Sci. 111:10239-10244.

Dumont HJ, Van de Velde I, Dumont S, 1975. The dry weight estimate of biomass in selection of Cladocera, Copepoda and Rotifera from the plankton, periphyton and benthos of continental waters. Oecologia 19:75-97. 
Ejsmont-Karabin J, Karpowicz M, 2019. Epizoic rotifers on Dreissena polymorpha in relations to biotic factors. Hydrobiologia 828:137-145.

Finlay BJ, 1982. Procedures for the isolation, cultivation and identification of protozoa. Experiment. Microb. Ecol. 1:44-65.

Foissner W, Berger H, Schaumburg J, 1999. Identification and ecology of limnetic plankton ciliates. Informationsberichte des Bayer. Landesamtes für Wasserwirtschaft, München.

Foissner W, Berger H, 1996. A user-friendly guide to the ciliates (Protozoa, Ciliophora) commonly used by hydrobiologists as bioindicators in rivers, lakes and waste waters, with notes on their ecology. Freshw. Biol. 35:375-470.

Gaiser EE, Childers DL, Jones RD, Richards JH, Scinto LJ, Texler JC, 2006. Periphyton responses to eutrophication in the Florida Everglades: cross-system patterns of structural and compositional change. Limnol. Oceanogr. 51:617-630.

Gilbert D, Amblard C, Bourdier G, Francez AJ, 1998. The microbial loop at the surface of a peatland: structure, functioning and impact of nutrients inputs. Microb. Ecol. 35:89-93.

Golterman HL, 1969. Methods for chemical analysis of freshwaters. Blackwell Scientific Publications, Oxford, Edinburgh.

Gregory MR, 2009. Environmental implications of plastic debris in marine settings-entanglement, ingestion, smothering, hangers-on, hitch-hiking and alien invasions. Phil. Trans.R. Soc. B. 364:2013-2025.

Hermanowicz W, Dożańska W, Dolido J, Koziorowski B, 1976. Physical and chemical investigation methods of water and sewage. Arkady, Warsaw, Poland.

Hillebrand H, Sommer U, 2000. Effect of continuous nutrient enrichment on microalgae colonizing hard substrates. Hydrobiologia 426:185-192.

Kalinowska K, Ejsmont-Karabin J, Gorelysheva Z, Rybak IJ, 2012. Biomass distribution and dynamics and food web relations in psammon community of a eutrophic lake. Pol. J. Ecol. 60:443-453.

Kaur P, Mehra NK, 1994. An evaluation of a new method for quantitative analysis of epiphytic biota on roots of water hyacinth. Verhandlungen der International Association of Theoretical and Applied Limnology 25:1137-1141.

Law KL, Morèt-Ferguson S, Maximenko NA, Proskurowski G, Peacock EE, Hafner J, Reddy CM, 2010. Plastic accumulation in the North Atlantic subtropical gyre. Sci. 329 (5996):1185-1188.

Madoni P, Zangrossi S, 2005. Ciliated protozoa and saprobical evaluation of water quality in the Taro River (northern Italy). Ital. J. Zool.72:21-25.

Mieczan T, Rudyk-Leuska N, 2019. Seasonal dynamics of the epibiont food web on Unio tumidus (Philipsson, 1788) in eutrophic reservoir. Europ. J. Protistol. 69:138-150.

Mieczan T, 2006. Studies on the colonization and succession patterns of periphytic ciliates communities on natural and artificial substrata in two lakes of different trophic status. Pol. J. Environ. Stud. 15/5d:557-561.

Mieczan T, 2007. Comparative study of periphytic ciliate communities colonization and succession on natural and artificial substrata in two shallow lakes (Eastern Poland). Annal. de Limnol. Internat. J. Limnol. 3:179-186.

Moeller RE, Burkholder JM, Wetzel RG, 1988. Significance of sedimentary phosphorous to a rooted submersed macrophyte (Najas flexilis (Willd.) Rostk. and Schmidt) and its algal epiphytes. Aquat. Bot. 32:261-281.

Napiórkowski P, Bąkowska M, Mrozińska N, Szymańska M, Kolarova N, Obolewski K, 2019. The Effect of Hydrological Connectivity on the Zooplankton Structure in Floodplain Lakes of a Regulated Large River (the Lower Vistula, Poland). Water 11:1924, https://doi.org/10.3390/w11091924.

Oberbeckmann S, Osborn AM, Duhaime MB, 2016. Microbes on a bottle: substrate, season and geography influence community composition on microbes colonizing marine plastic debris. PLOS One, doi: 10.1371/journal.pone. 0159289.

Pernthaler J., Glöckner F.O., Schonhuber W., Amann R. 2001. Fluorescence in situ hybridization with rRNA-targeted aligonucleotide probes. Methods Microbiol. 30:207-226.

Porter KG, Feig YS, 1980. The use of DAPI for identifying and counting aquatic microflora. Limnol. Oceanogr. 25:943-948.

Primc-Habdija B, Habdija J, Plenković-Moraj A, Špoljar M, 1997. The overgrowth capacity of periphyton on artificial substrates exposed at vertical profile in the Lake Visovac. Period. Biol. 99:403-408.

Rott E, 1981. Some results from phytoplankton counting intercalibrations. Schweiz. Z. Hydrol. 43:34-62.

Ruttner-Kolisko A, 1974. Plankton rotifers: biology and taxonomy. Die Binnengewässer, Stuttgart, Germany.

Strüder-Kypke MC, 1999. Periphyton and sphagnicolus protists of dystrophic bog lakes (Brandenburg, Germany). Limnologica 29:393-406.

Ter Braak CJF, Šmilauer P, 2002. CANOCO-FORTRAN program for Canonical Community Ordination (vers. 2.1). Microcomputer Power, Ithaca.

van den Hoek C, Mann DG, Jahns HM, 1995. Algae. An introduction to phycology. Cambridge University Press, Cambridge.

Wang T, Li Y, Xu T, Wu N, Liang M, Hynds P, 2016. Biofilm microbial community structure in an urban lake utilizing reclaimed water. Environ. Earth. Sci. 75:314. 